\title{
Political Participation of the Brazilian Indigenous Movement and the Effectiveness of Fundamental Human Rights
}

\author{
Luciano Alberto Ferreira1 ${ }^{*}$, Ana Claudia Santano², Verçulina Firmino dos Santos ${ }^{3}$ \\ ${ }^{1}$ School of Law, Pontifical Catholic University of Paraná, Curitiba, Brazil \\ ${ }^{2}$ School of Law, Autonomous University Center of Brazil, UniBrasil, Curitiba, Brazil \\ ${ }^{3}$ Center for Administrative and Economic Sciences, Roraima Federal University, Boa Vista, Brazil \\ Email: ^luciano.alberto@pucpr.edu.br, anaclaudiasantano@yahoo.com.br, versulinafirmino@gmail.com
}

How to cite this paper: Ferreira, L. A., Santano, A. C., \& dos Santos, V. F. (2021). Political Participation of the Brazilian Indigenous Movement and the Effectiveness of Fundamental Human Rights. Beijing Law Review, 12, 91-112.

https://doi.org/10.4236/blr.2021.121006

Received: January 25, 2021

Accepted: March 9, 2021

Published: March 12, 2021

Copyright $\odot 2021$ by author(s) and Scientific Research Publishing Inc. This work is licensed under the Creative Commons Attribution International License (CC BY 4.0).

http://creativecommons.org/licenses/by/4.0/

\begin{abstract}
This paper attends with the relationship between the indigenous movement and the public sphere through political participation as a means of realizing human dignity according to Brazilian and Latin American perspectives. The objective is to qualify the performance of this movement in the Brazilian public sphere through the National Council for Indigenous Policy (originally CNPI) and the prior consultation protocol provided for in ILO Convention No. 169. The levels and degrees of participation of Juan E. Díaz Bordenave and the levels of the public sphere of John Keane are considered. The exploratory and comparative study involves indirect documentation. The findings' analysis suggests that the political participation of the indigenous movement in CNPI is limited to the meso-public sphere of spaces institutionalized by the state's government, with little capacity for political protagonism. In contrast, the implementation of the prior consultation protocols articulates the different levels of the public sphere. It expresses greater political protagonism of Brazilian indigenous peoples, which can provide a more effective Brazilian indigenous people's political intervention system toward gathering comprehensively fundamental human rights of different dimensions in promoting human dignity.
\end{abstract}

\section{Keywords}

Political Participation, Public Sphere, Brazilian Indigenous Movement, Fundamental Human Rights

\section{Introduction}

The hegemonic conception of civil society has its sources in the political and le- 
gal traditions of the way of life in the Western world, especially in the sense of equal political participation. Concomitantly, there is also a tendency to replace the old hegemony of life and the public sphere led by the state with a multiplicity of networks (Keane, 2001), which has favored the recognition of their own and differentiated cultural identities (many times translated by social organization, customs, languages, beliefs and specific traditions), such as those of indigenous peoples, thus consolidating the end of five centuries of integrationist politics (Souza Filho, 2012, Ferraz \& Caballero, 2014), and providing greater empowerment to the indigenous movement in the public sphere, including the recognition of the human right to political participation.

In this sense, this paper proposes a study about the relationship between Brazilian indigenous movement and Brazilian public sphere using two instruments of political participation: the National Council for Indigenous Policy, an institutionalized democratic State space, and the implementation of the anticipated consultation protocol in ILO Convention 169. The objective is to qualify the performance of this movement in the Brazilian public sphere through these instruments of political participation. As a theoretical contribution, the levels and degrees of social participation proposed by Juan E. Díaz Bordenave are considered to evaluate the quality of participation, and the levels of the public sphere of John Keane are considered in order to capture the articulation capacity provided by the participatory instruments Brazilian indigenous peoples.

To mapping this work, political participation could be understanding as a fundamental human right in the contemporary representative democracy by which different interest groups make their demands before public spheres, make governments accountable and responsive, and influence some political outcomes, especially the production, management, and enjoyment of the goods produced by a society (United Nations News Center, 2013, Toerell, Torcal, \& Montero, 2007, Bordenave, 1994, Baraldi \& Peruzzo, 2015).

The term indigenous movement is used herein Latin American sociological terms, as an ethno-politic process, with ethnicity's strategic use for political purposes. This process more or less spreads a set of organizational and action forms, which tries to bring together integrated ethnic groups in different situations and interethnic systems, aiming at intervention in a political system toward social justice (Ferreira, 2017; Deus, 2020; Lembke, 2006).

Therefore, an exploratory and comparative study was developed with the use of indirect documentation, especially bylaws and plenary resolutions available on the website of that council, in addition to articles, magazines and books on the subject.

\section{Human Rights and Their Participatory Dimension}

In both dogmatic-normative and theoretical-academic grounds, the right to political participation has been configured as a fundamental human right. Due to its indivisible and interdependent quality, the positive and negative commands 
of state and society promoting and realizing human dignity are related.

These aspects reveal a participatory dimension of human right that have shaped the democracies, with the instrumentalization of individual rights toward the social rights in the realization of human dignity, overcoming the dichotomy of the rights of freedom and the rights of equality. This pathway toward a comprehensive dimension of human rights can be engineered by political participation put forward by the international human rights system, states' constitutional system, and social-political movements, which could be expressed by indigenous movement.

Within the scope of the international human rights system, the right to political participation is highlighted in art. 21 of the Universal Declaration of Human Rights, especially in paragraph 1 , by providing for everyone "the right to take part in the direction of public affairs in their country, either directly or through freely chosen representatives", and in the International Covenant on Civil and Political Rights, promulgated by the Brazilian State in 1992, which establishes in its article 25 that every citizen should have the right and the possibility to "participate in the conduct of public affairs, directly or through representatives freely".

This International Covenant expressly linked human rights and human dignity by stating that the rights enumerated "derive from the inherent dignity of the human person", which is commonly cited in international laws and literature (Donnelly, 1982).

However, bearing in mind Ronald Dworkin's distinction between concept and conception, in a conceptual level, human rights are the rights which one has because this one is a human being person (Donnelly, 1982). In contrast, at a conception level, rights, persons, and inherent human dignity are central ideas that need to be explained in distinctive societies to develop a political practice list (Donnelly, 1982). Additionally, the meaning of dignity tends to vary significantly from jurisdiction to jurisdiction and even over time within certain jurisdictions (McCrudden, 2008).

Therefore, in these two levels, the fundamental human right to political participation can be elaborated and interpreted in the comprehensive dimension and consider its indivisible and interdependent nature to protect and realize human dignity. That way, it is possible to articulate rights of freedom and the rights of equality at the same time in the first step to overcome some threats and difficulties due to different approaches among the diversity of society's culture and traditions and within other jurisdictions.

In this sense, the political participation has been debated at the UN level as a right related to empowerment, considered a goal and principle of great relevance to human rights, and which plays an important role in breaking ingrained inequalities and hierarchies (United Nations News Center, 2013).

Thus, this search for equality through the freedom to participate is also present at the regional level. The Organization of American States (OAS) Charter, considered a formal framework that sets goals and proclaims the respect for 
human rights by all 35 independent countries of the Americas (Santano, 2019: p. 277), brings the right to participation as one of the mechanisms designed to achieve the full realization of human aspirations "within a just social order". The American Declaration of the Rights and Duties of Man (1948) states in its art. 20 that every capable person "has the right to take part in the government of his country, either directly or through his representatives". One cannot forget that, regarding the coercive power of this Charter, the hermeneutic framework established "for the interpretation of human rights in the inter-American system" disallows the separation of the OAS Charter from the American Declaration of the Rights and Duties of Man when analyzing the rights contained therein in any specific case (Santano, 2019: p. 278).

It should be noted that, despite the notably individualistic character of these instruments, a recurring object of criticism from several critical theoretical currents, especially Marxists, postcolonial and decolonial (Leff, 2001; Delmas-Marty, 2001; Henriques, 2014; Walsh, 2008; Bragato, 2014; Almeida \& Silva, 2015), the opening to a hermeneutics towards the democratization of access to goods and services of social interest became formally possible with the instrumentalization of individual human rights related to a civil and political issues, especially by allowing social actors outside the bureaucratic-state to have the possibility of acting (or at least influencing) in the decision-making process of public policies and the organization of society.

It is suggested, therefore, the overcoming of the supposed dichotomy of human rights based on the alleged difficulty of reconciling the rights of freedom and the rights of equality, which can be explained by the indivisible and interdependent nature of human rights. In Brazil, Ana Claudia Santano and others clarifies the significant nucleus of indivisibility and interdependence in the scope of human rights: indivisibility related to the idea that all human rights deserve the same legal protection, since they are elementary to achieve a dignified life; whereas the interdependence (or interrelationship) of these rights is related to the recognition that they all contribute to the realization of a dignified life and interact with each other towards this goal, again engendering their indivisibility (Santano, 2019: p. 282; Hachem \& Bonat, 2017; Mezzaroba \& Silveira, 2018).

Recent Inter-American Court's jurisprudence were based on the indirect protection of social rights through the exercise of civil and political rights (individual rights par excellence), highlighting two emblematic cases: Albán Cornejo and others v. Ecuador, regarding the alleged medical negligence in a private hospital, whose decision was based on the protection of the right personal integrity and not the social right to health, and Acevedo Buendia vs. Peru, when was explicitly recognized that human rights must be interpreted considering their integrality and interdependence, combining civil and political rights and economic, social and cultural rights, also affirming the absence of any hierarchy between them, all of which are enforceable rights (Piovesan, 2017: p. 1356-1388).

The interpretation and application of these rights in an indivisible and inter- 
dependent way in the context of the National States with evident cultural diversity disregard the differentiation of the terms "Human Rights" and "Fundamental Rights".

Considering the conceptual proximity of the expressions human rights and fundamental rights, founded on the existence of certain universal and timeless principles (the moral rights) that resulted initially from the historical confluence of the modernity of the "century of lights" and the creation of the liberal rule of law, went through the enlargement "of the constitutional consensus beyond the bourgeoisie", and which resurfaced in the center of the debate after the horrors of the Second World War. Today the use of these expressions is marked by the ambivalences of the political, economic and social results of the phenomenon of globalization, and the difference between them was limited to a mere space-territorial aspect, in the sense that Fundamental Rights have been seen as prerogatives recognized by the internal legal order of each State, and Human Rights are related "to the prerogatives which are recognized by the international legal orbit" (Rossi, 2019: p. 212-225; United Nations News Center, 2013).

Therefore, human rights and fundamental rights should not be seen as distinct orders, but as harmonious expressions in the realization of human dignity in all its dimensions and spaces, being able to say Fundamental Human Rights (Rossi, 2019: p. 230, Cademartori \& Grubba, 2012: p. 711, United Nations News Center, 2013).

In Brazil, with citizenship as one of its foundations (Article 1), the Constitution of the Federative Republic of Brazil (CFRB/1988) establishes various mechanisms for the realization of human dignity through the right to political participation, especially related to public management, as can be seen for instance in Article 198, which deals with "public health actions and services" and establishes as a guideline the participation of the community in the management of the related activities; and in Article 204, which deals with "governmental actions in the area of social assistance", which must be organized based on the guideline of "population participation, through representative organizations, in the formulation of policies and in the control of actions at all levels".

In spite of the fruitful theoretical and normative production of the sense of political participation as a means and an end to the exercise of fundamental human rights, there is an urgent need to understand the instruments available and the conditions of action of civil society agents, especially indigenous people, before the public spheres that they permeate and involve state activities in the material realization of human dignity, especially through political participation.

It is not too much to remember the long journey of native Brazilian people in the recent process of political participation and shaping the national public agenda, especially after they overcome the integration and assimilation policies that conceived them as obstacles to national development and realization of modernity. CFRB/1988 and recent Brazilian court decisions expressly express this turn on Brazilian indigenous policy, especially when recognizing the rights 
to be and remain indigenous, admitting the existence of collective rights related to the way of life of these peoples and overcoming interpretations of archaic definitions of the term "sylvan" in national normative texts, for example (Souza Filho, 2012: p. 90-91).

In this new context, Brazilian indigenous peoples assume a prominent role in the Brazilian public sphere, mainly through an ethno-politic process, as described in section 1 .

\section{Political Participation through Public Spheres}

In the contemporary world, political participation demands interactions between multiple agents in different spaces and dimensions, which have been of great value for the empowerment of minority groups such as indigenous peoples. In this sense, it is essential to understand the arenas where multiple identities and interests are articulated to influence public's agendas and political participation as a critical activity for constructing the Democratic Rule of Law.

\subsection{The Contemporary Public Sphere}

The public sphere and the state are not otherwise words with the same meaning, nor is the notion of separation between them something new in Western history. The notion of separation between state and civil society has its roots in the beginning of the Middle Ages, with the conception of political authority as just another organ among others, with the idea of the Church as an independent society, conception of subjective rights based on mutual relations that implied rights and obligations between feudal lords and vassals, creation of standard political structures among the various medieval communities, and the monarch's dependence on the support of various States. It is precisely this context that created the general notion of non-identity between society and its political organization, laying the foundations for a later civil society notion of Western liberalism (Taylor, 2000: p. 222-228).

Today, civil society can be understanding as an amalgamation of decisions that impel to conceive it as free associations and without the tutelage of the State, as structured and coordinated by actions of these free associations, or additionally as a set of associations that can significantly determine the direction of a given State policy (Taylor, 2000: p. 240).

Considering that this civil society operates within the public spheres, it is urgent to inquire how this civil society manifests itself today in the midst of networks of power relations that shape State and non-state public agendas in the face of the concomitant demands for freedom and equality.

A vital element of civil society, the public sphere today tends to renew in the sense of creating a complex mosaic of spaces on different dimensions, most of them overlapping and interconnected. Thus, the conception of political authority as just another one among others, guiding us in the sense of a radical revision of analogous expressions such as public opinion, public good, and public-private 
distinction (Keane, 2001: p. 222-228).

In this conception coming from all corners and recesses of civil society and the State, the public spheres are stages of action linked to power and interests, which have the effect of desecrating the power relations (according to Michael Foucault), naming the unnameable (made by militant agendas), pointing out frauds, taking sides, initiating discussions, inducing diffidenza (caution or skepticism), in short, "shaking the world" (Keane, 2001: p. 195).

In this sense, there seems to be greater openness to the plurality of individuals and groups to express their solidarity or opposition to the ideas and forms of life of others autonomously, without the definitive predominance of the futile and dangerous highways of transhistorical ideals and definitive truths, so that there is an inexplicable and inconceivable real-life rebellion that operates outside the reach of theoretical elaborations of the $19^{\text {th }}$ century and far from the universal sense of world salvation and ecology captured by socialists, conservatives or green theorists (Keane, 2001).

So, these public spheres are not linked to the definition of what is called political society, that is, the area of social life closely interwoven between the world of power and money (state and economy) and the pre-political group associations of civil society. Public spheres develop in various fields of civil society and state institutions, within the territory of the consumer market, and even in the world of power beyond the reach of territorial nation-states (Keane, 2001: p. 195-206).

For purely analytical purposes, Keane (2001) classifies the public spheres into three levels: micro-public spheres, active at the sub-state level, vital for social movements, where social identities are forged and where they often act at a distance from official public life, operating a redistribution of exercise of power by acting in the corners and recesses of civil society; meso-public spheres, which operates in the state, regional or close to national borders, usually mediated by newspapers or other means of great circulation of news, feeding on tensions that it maintains with agents from other spheres; and macro-public spheres, at a broader global or regional level, generally conducted for reasons of political economy, with a great capacity to escape the regulations of national states and to promote public controversies about power and principles.

\subsection{Political Participation of Minority Groups in Brazil's Public Spheres}

Among these public spheres, political participation, a relevant topic about contemporary democracy in western countries described in section 1 , may be seen as an effective pathway to provide effectiveness to human rights.

When it comes to the participation of minority groups in the public spheres in Brazil, do not forget that the objectives in the CFRB/ 1988 as building a free, just and solidary society (article 3, item I) and the promotion of the good all, without prejudice of origin, race, sex, color, age and any other forms of discrimination (article 3, item IV), tends to establish a hermeneutic basis that allows a more participatory and open reading of the Brazilian legal system, admitting the 
people as a plural set of those who are the true holders of power (Baraldi \& Peruzzo, 2015).

Consequently, the quality of the political participation of the indigenous movement could be inquired, as a fundamental human right and an agglutinating element of agents from public spheres, especially when formulating and implementing public policy agendas and other legal and administrative actions that may affect their living conditions.

A relevant instrument for analyzing the participation of any social group in the public sphere, whether in the formulation of policies, or as a means of overcoming the difficulties arising from the crisis of representation, is the evaluation of the existing and possible forms of participation for a given social group, whether by through institutions formalized in governmental organizations, either through social and political mobilization involving other groups and social interests at different levels of the public sphere.

\section{A Proposal for Assessing Political Participation}

According Bordenave (1994: p. 23), the litmus test of participation "is not how much you take part, but how you take part". Therefore, it is important to bring to the fore the possible forms of participation for those who work in the multiple spaces of the public sphere, taking into account their degrees and levels treated by the author.

As for the degrees of participation, there are the categories information, optional consultation, elaboration or recommendation, co-management, delegation and self-management, as defined below (Bordenave, 1994: p. 31-33).

The category "information" refers to the most elementary level of participation, whereby managers only inform decisions already taken to members or participants of a specific collegiality.

Through the "optional consultation", the directors have the option of consulting the other participants in the public sphere, being able to accept criticisms, suggestions or even data in order to solve problems. Consultation can also be considered mandatory. However, in any of these modalities, the final decision is left to the managers.

In turn, the category "elaboration or recommendation" is a still low degree of participation, when non-managerial participants are allowed to elaborate proposals and recommend measures that can be justifiably rejected by managers. "Co-management", on the other hand, involves sharing the administration through codecision and collegiality, using committees, councils and other collegiate forms.

The "delegation", in turn, involves greater autonomy of the participants in areas, subjects or even jurisdictions that were previously reserved only for the leaders or authorities. In any case, the delegates were "authorized" specifically by those who held some authority. Finally, the highest degree of participation elaborated by Bordenave is "self-management", when participants are free to de- 
termine their objectives, choose their means and create standards of control, without necessary deference to any external authority or leader.

Participation in the public sphere can also be qualified based on levels, taking into consideration the importance of decisions related to a particular space of discussion and deliberation. To this end, the six-level of participation are presented in decreasing order of importance: Level 1-formulation of the institution's doctrine and policy; Level 2-formulation of objectives and strategies; Level 3-formulation of plans, programs, and projects; Level 4-resource allocation and project management; Level 5-execution of actions; and Level 6-evaluation of results (Bordenave, 1994: p. 33-35). For the author, participation in levels 5 and 6 has a high probability of conceiving great value to bureaucratic and technocratic backgrounds, for example, to the detriment of a more democratic and effective social participation. However, participation at levels 1, 2,3 , and 4 reveals a growing political maturity of participants and institutions in the sense of greater democratization of the public sphere.

In this case, to carry out an analysis of the quality of political participation of the indigenous movement, it is preliminarily necessary to know the recent "rebirth" of indigenous peoples to the Brazilian public sphere.

The "rebirth of indigenous peoples for the Law" (Souza Filho, 2012) highlights a long path of struggle for these stateless peoples who had needed to negotiate their rights of existence with national states which came after. When Latin Americans national states were formally constituted they forgot their indigenous peoples, except for the integrationist policy that insisted on subduing all these peoples on the same territory under a single jurisdiction. In this context, indigenous peoples were considered temporary passengers in a situation of change, when everyone would become a single mass of citizens, stripped of their cultural and ethnic peculiarities, in other words, they were just legal gaps that could be resolved over time. Besides, an integrationist conception of indigenous peoples in Brazil prevailed, clearly expressed in the Indian Statute Act (Federal Public Law No. 6.001/1973).

Fortunately, this integrationist conception and the invisibility of indigenous peoples were expressly revoked in Brazil with CFRB/1988, especially with art. 231, which stated the right to be indigenous, by accepting "its social organization, customs, languages, beliefs and traditions", in addition to other rights over indigenous heritage (Cunha, 2018: p. 440). Important to remember that this achievement is part of a process of leading the indigenous cause at the three levels of contemporary public spheres already addressed by Keane, who often operate in a connected and simultaneous manner.

Thus, Brazilian indigenous peoples also rebirth for the public sphere and for political participation after remained for a long time as romanticized, controversial figures or even as legal gaps in the face of the public and private dichotomy.

Within the scope of public micro-spheres, multiple indigenous communities began to organize themselves around local causes, such as defenses of already 
demarcated territories, and combating illegal mining and deforestation. In the meso-public spheres, the work of non-governmental organizations, voluntary supporting groups, national political parties, and the media has been strong enough to bring the indigenous issue to the public debate in an extremely efficient manner. In turn, in the macro-public sphere, the indigenous theme has been repeatedly treated as a human rights issue, despite the controversies of this treatment pointed out by authors of critical theories, so that global entities such as the United Nations, International Organization of the Labor, UNESCO, the Organization of American States, non-governmental organizations, and the global media, have proved to be important players.

\section{Assessing the Main Instruments of Political Participation Available to Brazilian Indigenous Peoples}

From the opening to the plurality of individuals and groups in the formation of the public sphere at different levels, it is possible to question the quality of the political participation of the indigenous movement in the formulation of state policies from two instruments of political participation available to Brazilian indigenous peoples: the National Policy Council Indigenous, institutionalized democratic state space, and the implementation of a prior consultation protocol, provided for ILO Convention No. 169.

These instruments' internal logical relationships comprise the conditions for the empowerment of agents or political groups in different arenas for discussion and formation of the public agenda, and their ability to articulate with other agents or political groups through the public sphere levels in defense of their interests.

\subsection{The Political Participation of Indigenous Peoples in the Public Sphere through the National Council for Indigenous Policy}

Although the demands of the majority of indigenous organizations are still mainly focused on territorial rights as of the 1990s, together with the explosion of social participation, their focus of action also shifted to projects in education, health, commercialization, and territorial management (Ferreira, 2017).

More recently a public sphere was institutionalized by the Brazilian State, on April 27, 2016, to address indigenous public policies, the National Council for Indigenous Policy (originally CNPI). Although this council is among those threatened by the Executive Order No. 9,759/2019, which extinguished and established guidelines, rules that would limit the performance of collegiate bodies of the direct, autarchic and foundational federal public administration, the purpose of this work is to know the conditions of participation from documents that tell part of the history of the indigenous movement in the Brazilian public sphere, in the sense of indicating paths that have been taken and obstacles that would be overcome.

The Council, created by Executive Order No. 8593 of December 17, 2015, 
within the scope of the Ministry of Justice, replaced the older National Commission for Indigenous Policy. The collegiate body kept the same acronym as the old CNPI, however, with greater representation, acting in the elaboration, monitoring, and implementation of public policies aimed at Brazilian indigenous people.

The Council is structured by the presidency, vice-presidency, executive secretary, plenary, and six thematic chambers (Funai, 2020). The CNPI Plenary meets ordinarily every three months, and, extraordinarily, whenever the President or the absolute majority of its members convenes it. Representatives of indigenous peoples and indigenous organizations have the right to meet, before ordinary or extraordinary meetings, on the day immediately before the Council meeting.

Following Rules of Procedure Article 11, the deliberations of the CNPI plenary meetings will be the subject of resolutions, signed by the president and published in the Official Gazette of the Union (DOU), which may be through opinions, recommendations, motions of applause or rejection (Justice Ministry, 2016).

The main competencies of CNPI are presented in Article 1 of its Internal Regulations, among which highlight to propose objectives, principles, and guidelines for public policies aimed at indigenous peoples; to propose priorities and criteria for the conduct of indigenous policy, in compliance with the legislation in force; to monitor the execution of public policy actions aimed at indigenous peoples; to support the integration and articulation of Organs governmental and non-governmental organizations that are members of CNPI that work with indigenous peoples or whose actions may have an impact on them; to encourage the implementation and harmonization between specific public policies, differentiated and directed to indigenous peoples; to support and promote the organization of events organized by indigenous peoples, especially for the debate and improvement of the policy proposals addressed to them; to monitor the preparation and execution of the Union's budget, within the scope of public policies aimed at indigenous peoples; to monitor and, eventually, receive and forward, complaints of threat or violation of the rights of the community or indigenous people sent to Organs competent bodies, recommending measures; and to follow up on regulatory proposals and administrative and judicial decisions that may affect the rights of indigenous peoples (Justice Ministry, 2016).

About the level of participation, prima facie, the high quality of the political participation of the indigenous movement in this institutionalized public sphere remains evident, since when proposing objectives, principles, guidelines, priorities, and criteria to indigenous policies, and propose the holding of National Conferences of Indigenous Policy, and to monitor the elaboration and execution of the Union budget. Thus, the performance of the indigenous movement at CNPI is situated at levels 1, 2, 3 and 4 of level of participation presented by Bordenave (1994).

On the other hand, the Council's purely advisory character draws attention, 
according to Article 1 of the CNPI Internal Regulations: "To the National Council for Indigenous Policy, a collegiate body of an advisory nature responsible for the elaboration, monitoring, and implementation of public policies aimed at indigenous peoples" (Justice Ministry, 2016).

This fact is relevant, according to recent research which asserts that after 25 ordinary meetings and 9 extraordinary meetings, a political emptying of that public sphere was observed, given its consultative character, which weighs heavily on indigenous presence. Besides, government bodies are underrepresented because their members belong to the third or fourth administrative level, without any decision-making power. Thus, the CNPI "ends up being an empty social control instance" (Ferraz \& Caballero, 2014: p. 128).

Based on the categories of a degree of participation presented by Bordenave (1994), it is understood that although consultation is mandatory, the final decision would be the responsibility of executive directors or other powers, configuring an elementary and precarious degree of participation. Besides, the reality seems less favorable to indigenous peoples when they participate in CNPI, taking into account that government representatives lack decision-making power, which suggests a pre-established limit that differs from some degree of performance that suggests intercultural standard social participation of indigenous movements in the management of public policies aimed at the indigenous peoples of Brazil.

Another way of evaluating the effectiveness of the indigenous movement's participation in this state public sphere starts from the analysis of the themes and the directions given through the resolutions issued by the CNPI plenary.

The recurring themes at the Commission's meetings until 2014 were: health, the processing of PLS No. 169/2016, a bill shifts which institutes the New Statute for Indigenous Peoples, the revocation of Ordinance No. 303/2012 of the Federal Attorney-General (as known as AGU), which relativizes the exclusive use of natural resources in indigenous lands for the benefit of works of public interest in the Union, the indigenous school education, the restructuring of Funai, besides the land issues about demarcation, land clearing, and protection of indigenous lands (Ferraz \& Caballero, 2014: p. 128-133).

In the Council phase, from 2016 onwards, the focus of documentary analysis, the main themes dealt with from the approved resolutions were: the revocation of Ordinance no. 303/2012 of the Federal Attorney-General, the suspension of PLS No. 169/2016, that institutes the New Statute of Indigenous Peoples, and subsequent submission to CNPI for analysis and opinion, maintenance and expansion of demarcation of indigenous lands, refutation of the framework of the temporal thesis of the Federal Supreme Court about the demarcation of indigenous land, the judicial legitimacy of indigenous peoples, their communities, and organizations to enter into court, propose or urge action or adoption of measures to the powers and public bodies.

Considering the level of participation presented by Bordenave (1994), it re- 
mains evident that the themes dealt with in the public sphere in question are of high relevance for the realization of the rights of indigenous peoples already recognized by Brazilian society.

The performance of the social segments representative of Brazilian indigenous peoples around themes such as PLS No.169/2016, which institutes the New Statute of Indigenous Peoples, shows a high level of participation when it comes to formulating doctrine and institutional policy (Level 1). Although the performance before the proposal of this New Statute is at level 1 of political participation (National Council for Indigenous Policy, 2016b; Bordenave, 1994), there was no consultation with indigenous peoples on the referred PLS, contrary to the rule expressed in Article 6 of ILO Convention no. 169, for which reason it was requested by these people to suspend PLS 169/2016 and subsequently send it to CNPI for manifestation in a consultation degree, which in turn refers to an elementary degree of participation.

The struggle for the judicial procedural capacity to go to court in the defense of collective rights is another issue related to the highest level of participation, Level 1, since, undoubtedly, the search for this legitimacy is inserted in the formulation of doctrine and institutional policy at the national level which involves more than one of the powers of the Republic and is of interest to all indigenous peoples in Brazil. In this sense, through Resolution No. 05/CNPI, of 04/08/2016, representatives of the Brazilian indigenous movement asked the Supreme Federal Court "to recognize the legitimacy of indigenous peoples, their communities and organizations to go to court in defense of their rights and interests, as recommended by article 232 of the Brazilian Constitution" (National Council for Indigenous Policy, 2016e).

The issues surrounding Ordinance No. 303/2012 of the Federal Attorney-General, a persistent theme in the public agenda of the social segments interested in the indigenous cause, the refutation of the landmark of the STF temporal thesis and the maintenance and expansion of the demarcation of indigenous lands, are topics of high level of political participation, since they also deal with the formulation of doctrine and institutional policy (Level 1).

The revocation of Ordinance No. 303/2012 of the Federal Attorney-General, is a relevant issue of the Brazilian indigenous movement present at CNPI and shows a fight against "illegality, unconstitutionality, and damage to the democratic commitment to guarantee the rights of indigenous peoples" (National Council for Indigenous Policy, 2016a). This decree deals with the regulation of the activities of the units of the Federal Attorney-General concerning institutional safeguards to indigenous lands based on the understanding established by the Federal Supreme Court on Raposa Serra do Sol case (Augusto Affonso Botelho Neto v. União, 2009), and among other rules, as the possibility of relativizing the use of the riches of the soil, rivers, and lakes existing in indigenous lands, the prohibition of the expansion of the indigenous land already demarcated, and the participation of the federated entities in the administrative procedure of de- 
marcation of the indigenous lands stuck in their territories. From the above, it is evident that the theme is related to the highest level of participation, Level 1, in the sense of formulating doctrine and institutional policy.

The refutation of the landmark temporal thesis of the STF and the maintenance and expansion of the demarcation of indigenous lands (National Council for Indigenous Policy, 2016d) are also themes related to the highest level of participation, since they materialize the policy of the Brazilian State regarding the original rights over the lands the indigenous people traditionally occupy, expressed in art. 231 of CRFB/1988.

Finally, to propose or urge action or adoption of measures to public authorities and agencies (National Council for Indigenous Policy, 2016c, 2016f), is only an evaluation of results, which is the lowest level of participation.

Accordingly the degree of social participation elaborated by Bordenave (1994), all these forms of action place the indigenous movement within the scope of CNPI in low degrees, only as "consultation", when participants should be consulted on certain occasions, or at most as "Elaboration or Recommendation", when participants make proposals or recommend measures whose rejections can be justified by internal or external managers. This observation is not only due to the findings from the CNPI resolutions, but also due to the very nature of the Council expressed in the internal regulations.

For comparison purposes, it is important to present the recent discussions in Brazil about the right to consultation and prior, free, and informed consent as a mechanism for participation in political participation available to indigenous peoples.

\subsection{The Political Participation of Indigenous Peoples in the Public Sphere Based on the Protocols of Prior Consultation}

Legally effective in Brazil since 2004 through Executive Order No. 5.051/2004, the International Labor Organization (ILO) Convention 169, along with CFRB/1988, signals an important paradigm shift in the relationship between nationals States and stateless peoples, especially indigenous peoples, which has been occurring with the Constitutions of Latin America since the end of the $20^{\text {th }}$ century, when the integrationist ideology was definitively abandoned and the "existence of peoples as such, their social organization with internal norms, hierarchical dispositions and a sufficient territory for the physical and cultural reproduction" started to influence this relationship. Thus, each one of these stateless peoples have been shaped the relationship with the national States, "in the exercise of the internal decisions in its territory, whether in the strict relationship between its members" (Souza Filho, 2019: p. 21-25; Souza Filho, 2012: p. 90).

It is in this context that the protocol for prior consultation has been evolving in Brazilian legal theory and dogmatics. This consultation protocol derives from the right to consultation and prior, free and informed consent (CCPLI), provided for in articles 6, 7, 15, 16, 17 and 22 of ILO Convention No. 169 and in ar- 
ticles 19 and 32 of the United Nations Declaration on the Rights of Indigenous Peoples, and represents an expressive legal means that gives social effect to this paradigm shift about relationship between national states and stateless peoples.

ILO Convention No. 169 lays down in Article 6, number 1, (a), that governments should consult the indigenous, tribal peoples, and traditional peoples concerned, through "appropriate procedures and, particularly, through their representative institutions, whenever legislative or administrative measures that may affect them directly". In other words, any legal or administrative means that involves a project with a great socio-environmental impact, such as a highway, hydroelectric, railroad, and mining, and reaches specific indigenous, tribal peoples, or traditional people, must be consulted before this project even it was only approved in the courts and state agencies (Pontes Jr., 2019: p. 12).

Consultation and prior, free and informed consent differ from other participation mechanisms, since it guarantees the original peoples the right to intervene in any of the planning, formulation, elaboration and execution of legislative or administrative measures that may directly impact their way of life and the relationship with its territory (Giffoni, 2020). In this sense, the prior consultation protocol can be understood as a mechanism that realizes the fundamental human right to political participation.

Thus, the national State must consult in order "to reach an agreement and obtain consent on the proposed measures", according to ILO Convention No. 169 , article 6, number 2. Based on this consent, a Term of Agreement or contract can be signed, which "would establish the limits of the act or measure proposed by the State and its modus faciendi". Then, this agreement can be called a protocol, since it establishes the limits of express consent "and the exact consequences of the administrative or legislative action to be practiced" (Souza Filho, 2019: p. 33-34).

The dogmatic-juridical basis that can guarantee the realization of the fundamental human right to political participation from the application of this legal instrument must be shaped not only by rights established in international law and in the constitution of the national state, but also by the rights of each indigenous people (Instituto Internacional de Derecho y Sociedad, 2011).

In Brazil and most of Latin America States, the international instruments of indigenous rights are those already mentioned, ILO Convention n. 169 and the United Nations Declaration on the Rights of Indigenous Peoples, as well as the recommendations and decisions arising from the Inter-American Human Rights System (Fajardo, 2011).

In the Inter-American Human Rights System, a prominent judgment of the Inter-American Court of Human Rights (Inter-American Court) was in the Saramaka v. Suriname case, which verdict was pronounced in 2007. Treated as a traditional people in Suriname's domestic law, the Saramaka people were considered equivalent to tribal people in the ILO Convention 169 nomenclature, so the decision is extensible as a precedent to indigenous peoples (Federal Public 
Prosecutor's Office, 2019: p. 332). In this case, the Saramaka people had suffered from socio-environmental impacts that reduced subsistence resources and destroyed places that were sacred to them, even in the 1960s, when part of their territory was flooded by the construction of the Afobaka Hydroelectric Plant. Faced with the Surinamese Government's indifference to repairing the alleged damages, the Saramaka people took the case to the Inter-American Commission on Human Rights and, subsequently, to the Inter-American Court. In the sentence, the Inter-American Court stated that the Surinamese State's obligation to recognize the right to "prior, effective and fully informed consultations" related to the "delimitation, demarcation and granting of collective title over the Saramaka territory", and any act that may endanger territorial rights would be prohibited, "unless the State obtains the prior, free and informed consent of this people” (Federal Public Prosecutor's Office, 2019: p. 338). This decision consolidated in the Inter-American Human Rights System the effective participation of tribal peoples in the case of major projects of development or intervention with the potential to generate relevant impacts on the property rights of its members (Silva, 2019a: p. 93).

In another case, the Kichwa Sarayaku people v. Ecuador, the Inter-American Court established an understanding of the right to consultation and its prior character, the necessary good faith, its purpose as a search for agreement, as well as the "need for an informed, adequate and accessible consultation to the peoples" (Silva, 2019a: p. 93-94).

Within the scope of the Brazilian domestic law, based on Article 231 of the CRFB/1988, indigenous peoples have been increasing along with all levels of public spheres their social structures of decision and political participation according to "their social organization, customs, languages, beliefs, and traditions". The CFRB/1988 also determines, in its article $5, \S 2$, that the rights and guarantees expressed therein are not able to exclude "others arising from the regime and principles adopted by it, or from international treaties in which the Federative Republic of Brazil be a part" which attracts the validity of the rules of ILO Convention No. 169, highlighting those that empower indigenous peoples in terms of political participation.

Therefore, as the elaboration, interpretation, and registration of national legal norms must respect the views and development priorities of each indigenous people as recognized intrinsic rights (Instituto Internacional de Derecho y Sociedad, 2011), a minimum principle is suggested that could inform the application of the consultation protocol: respect for "jusdiversity", insofar as establishing sources minimum legal frameworks for the regulation of indigenous interests recognizes customary indigenous law alongside state law and international law.

In the Brazilian context, the State not only guarantees the political role of indigenous peoples by recognizing their social organization, and traditions but also by recognizing their judicial legitimacy, through "communities and organiza- 
tions", in defense of their rights and interests. In both devices, there is a prospect of realizing the right to choose the development priorities of each people, as accepted by Brazil through ILO Convention No. 169, article 7.

This way, it can be interpreted that the principle of equality stamped in the Article 5 of the CFRB/1988 expands and reaches the world of the senses through legal-anthropological equality from the application of the prior consultation protocol, since recognizes indigenous peoples the right to contest and propose, based on their knowledge, the necessary corrections to legislative or administrative measures that may directly affect them.

Despite the necessary valuation of these general principles of juridical-anthropological equality and respect for justice, the making of the consultation protocol does not follow a specific script for all peoples, only the rule of the protagonism of the indigenous community interested in the elaboration of this document is valid binding legal framework (Oliveira, 2019).

Homeland jurisprudence has mostly based the right to free, prior, and informed consultation and consent to indigenous and other traditional peoples, as in the judicial decisions that suspended environmental licensing procedures for non-compliance with the effective conduct of free, prior, and informed consultation in cases involving communities of artisanal, riverside, and indigenous fishermen, such as those affected by the Belo Monte HPP works and others threatened by activities designed by Canadian mining company Belo Sun, both in Pará (Pinheiro Filho \& Silva, 2019; Silva, 2019a, 2019b: p. 5-6).

Thus, it can be asserted that the obligation of consultation and consent resulting from ILO Convention 169 gives the greater capacity for empowerment to the traditional peoples concerned, surpassing the mere pending consultation of an external decision in the context of a collegiate institutionalized by the State, since the positioning of these expressed in the consultation protocol, has a greater capacity for interference by indigenous peoples, and other traditional peoples in the decision-making process of public or private projects and initiatives that may jeopardize their fundamental collective human rights, especially those related to land and communities conditions of life for each cultural identity.

Furthermore, the association of indigenous peoples with agents of varying levels in the public sphere in a distinct way from what happens through participation in CNPI seems to contribute to their empowerment.

All consultation protocols of Brazilian indigenous peoples such as those used by the Mundurucu, between Mato Grosso and Pará, Juruna (Yudjá), in Volta Grande do Xingu, Krenak, in Minas Gerais, Wajãpi, in Amapá, and Waimiri Atroari (Kinja), between Amazonas and Roraima, show the performance of Brazilian indigenous peoples in a network that involves various levels of the public sphere in the defense of their rights. In this sense, could be cited the Wajãpi people's initiative, who had the assistance of the Amazon Cooperation Network - RCA and the Institute of Research and Indigenous Training - Iepé, and support from the Rainforest Foundation Norway, and the Yanomami's protocol, advised 
by the Instituto Socioambiental - ISA, a Civil Society Organization of Public Interest (OSCIP) based in São Paulo (Brazil) and subsidiaries in several cities in Brazil (Instituto Socioambiental, 2011), which aroused the sense of need of the Waimiri Atroari people regarding the elaboration of their consultation protocol (Oliveira, 2019: p. 126-201). All these consultation protocols grounded their arguments on ethnicity's strategic issues.

\section{Research Findings' Analysis}

It seems that, on the one hand, the political participation of the indigenous movement in public spheres with significant state influence, primarily through CNPI, does not fit with the realization of human dignity due to their low quality in terms of degrees of participation, especially keeping in mind the limited possibility of articulation through CNPI, which is restricted to the meso-political sphere in an institutionalized consultative space mostly controlled by the state government.

On the other hand, it is evident that political participation through protocols of prior consultation, elaborated from the legal dogmatic related to the ILO Convention 169, including different international norms and jurisprudence, as well as CFRB/1988 and national jurisprudence, even though through this original consultation nature, tends to be more effective in the comprehensive realization of human dignity. According the Brazilian's cited authors the position of Brazilian's indigenous peoples, expressed in the consultation protocol in the sense of fundamental individual right to political participation, has a greater capacity for interference in the decision-making process of public or private projects and initiatives that may jeopardize their fundamental collective human rights, such communal lands properties, cultural identity, and others.

It became also evident that the possibility of greater articulation with various agents from the micro-public, meso-public and macro-public spheres, including reaching the world of power outside the control of the Brazilian state, has contributed to the emergence of indigenous' agendas in the Brazilian public sphere and their empowerment.

Furthermore, indigenous' political participation could also be seen as a multicultural and ethnic political process, with strategic use of arguments grounded in respect of general indigenous customary, cultural identity, traditional subsistence resources, sacred places, social organization, indigenous community internal norms, and way of life according to each ethnicity group, and the application of the general principles of juridical-anthropological equality on the protocols of prior consultation established by ILO Convention 169.

\section{Conclusion}

The work sought to qualify the political participation of the indigenous movement in the Brazilian public sphere through their performance as members of CNPI and when implementing the prior consultation protocols provided for in 
ILO Convention No. 169.

The research findings set forth the indivisible and interdependent nature of human rights, asserting the comprehensive human dignity realization through articulating individual rights and collective rights; i.e., the guarantee of the fundamental collective rights of indigenous peoples can be achieved through the activation of fundamental human rights historically enshrined in the West to the individual in the civil and political sphere: the political participation.

Also, bearing in mind the concept of indigenous movement used herein Latin American sociological terms as an ethno-politic activity, it is possible to come to the understanding that the ethnicity's strategic use for political purposes by the prior consultation protocols provided for in ILO Convention No. 169, can provide a more effective Brazilian indigenous people's political intervention system toward to gathering comprehensively fundamental human rights of different dimensions in the promotion of human dignity.

Thus, the comprehensive dimension of indigenous' political participation in Brazil could be engendered due to the indivisible and interdependent nature of fundamental human rights and the political process's multicultural and ethnic character carried out by the indigenous movement.

Considering the exploratory nature of this work, more studies on the dynamics of interest groups in the Brazilian public sphere could be relevant to identify the discourses underlying the speeches of the social actors in those ethno-politic processes.

\section{Conflicts of Interest}

The authors declare no conflicts of interest regarding the publication of this paper.

\section{References}

Almeida, E. A., \& Silva, J. F. (2015). Abya Yala Como Território Epistêmico: Pensamento decolonial como perspectiva teórica. Revista Interterritórios, 1, 7-28. https://doi.org/10.33052/inter.v1i1.5009

Augusto Affonso Botelho Neto v. União, Supremo Tribunal Federal (2009). http://redir.stf.jus.br/paginadorpub/paginador.jsp?docTP=AC\&docID=630133

Baraldi, C. B. F., \& Peruzzo, P. P. (2015). Democracia e direitos humanos: A participação social das minorias. Revista Eletrônica do Curso de Direito da UFSM, 10, 346-370. https://doi.org/10.5902/1981369419769

Bordenave, J. D. (1994). O que é participação. São Paulo: Brasiliense.

Bragato, F. F. (2014). Para além do discurso eurocêntrico dos direitos humanos: Contribuições da descolonialidade. Novos estudos jurídicos, 19, 201-230.

https://doi.org/10.14210/nej.v19n1.p201-230

Cademartori, L. H. U., \& Grubba, L. S. (2012). O embasamento dos direitos humanos e sua relação com os direitos fundamentais a partir do diálogo garantista com a teoria da reinvenção dos direitos humanos. Revista de Direito GV, 8, 703-724.

https://doi.org/10.1590/S1808-24322012000200013 
Cunha, M. C. (2018). Índios na Constituição. Novos estudos, 37, 429-443.

Delmas-Marty, M. (2001). Acesso à humanidade em termos jurídicos. In E. Morin (Ed.), A Religação dos Saberes-O desafio do século XXI (pp. 227-235). Rio de Janeiro: Bertrand Brasil.

Deus, J. A. S. (2020). New Territorialities and Collective Ethnic Identities in the Brazilian Amazon Frontier, Rondonia State: Surui Paiter, Arara, and Gavião Indigenous Communities' Land Claims and Alternative Cultural Landscapes. In W. Leal Filho, V. King, \& I. Borges de Lima (Eds.), Indigenous Amazonia, Regional Development and Territorial Dynamics (pp. 181-195). The Latin American Studies Book Series, Berlin: Springer. https://doi.org/10.1007/978-3-030-29153-2_7

Donnelly, J. (1982). Human Rights and Human Dignity: An Analytic Critique of Non-Western Conceptions of Human Rights. The American Political Science Review, 76, 303-316. https://doi.org/10.2307/1961111

Fajardo, R. Z. Y. (2011). El derecho a la libre determinación del desarrollo, la participación, la consulta y el consentimiento.

http://www.derechoysociedad.org/IIDS/Documentos/El_Derecho_a_la_Libre_Determi na cion.pdf

Federal Public Prosecutor's Office (2019). Manual de jurisprudência dos direitos indígenas.

http://www.mpf.mp.br/atuacao-tematica/ccr6/documentos-e-publicacoes/manual-de-a tuacao/manual-de-jurisprudencia-dos-direitos-indigenas.pdf

Ferraz, I., \& Caballero, I. N. V. (2014). Movimentos indígenas: Luta por direitos ameaçados. In J. S. L. Lopes, \& B. Heredia (Eds.), Movimentos sociais e esfera pública: O mundo da participação (pp. 121-156). Rio de Janeiro: CBAE.

Ferreira, A. C. (2017). Etnopolítica e Estado: Centralização e descentralização no movimento indígena brasileiro. Anuário antropológico, 42, 195-226.

https://doi.org/10.4000/aa.1709

FUNAI (2020). Sobre o Conselho. http://www.funai.gov.br/index.php/cnpil/sinteses

Giffoni, J. F. (2020). Caminhos dos povos originários e o direito à Consulta Prévia, Livre e Informada.

https://www.editorajc.com.br/caminhos-dos-povos-originarios-e-o-direito-a-consultaprevia-livre-e-informada

Hachem, D. W., \& Bonat, A. (2017). O direito ao desenvolvimento de um projeto de vida na jurisprudência da Corte Interamericana de Direitos Humanos e a educação como elemento indispensável. Opinião Jurídica, 15, 77-105. https://doi.org/10.12662/2447-6641oj.v15i21.p77-105.2017

Henriques, M. B. (2014). A especificidade dos direitos dos povos indígenas e os limites do sistema internacional e latino-americano de proteção de direitos humanos. Revista Análisis Internacional, 5, 53-74.

Instituto Internacional de Derecho y Sociedad (2011). Principios mínimos para la aplicación de los derechos de participación, consulta previa y consentimiento previo, libre e informado.

http://www.derechoysociedad.org/IIDS/Documentos/PRINCIPIOS-MINIMOS_IIDS.p df

Instituto Socioambiental (2011). O ISA.

https://www.socioambiental.org/pt-br/o-isa

Justice Ministry (2016). Portaria $n^{\circ} 549$, de 6 de maio de 2016. Aprova o Regimento Interno do Conselho Nacional de Política Indigenista. 
http://www.funai.gov.br/arquivos/conteudo/presidencia/CNPI_Conselho/Atos_e_Nor mas/NORMAS/2016-05-06\%20-\%20PORT\%20549\%20-\%20Aprova\%20Regimento.pdf

Keane, J. (2001). A sociedade civil: Velhas imagens, novas visões. Braga: Temas e Debates.

Leff, E. (2001). Saber ambiental: Sustentabilidade, racionalidade, complexidade e poder. Petrópolis: Vozes.

Lembke, M. (2006). In the Lands of Oligarchs. Ethno-Politics and the Struggle for Social Justice in the Indigenous-Peasant Movements of Guatemala and Ecuador. Doctoral Dissertation, Stockholm: Stockholm University.

McCrudden, C. (2008). Human Dignity and Judicial Interpretation of Human Rights. The European Journal of International Law, 19, 655-724. https://doi.org/10.1093/ejil/chn043

Mezzaroba, O., \& Silveira, V. O. (2018). The Principle of the Dignity of Human Person: A Reading of the Effectiveness of Citizenship and Human Rights through the Challenges Putforward by Globalization. Revista de Investigações Constitucionais, 5, 273-293. https://doi.org/10.5380/rinc.v5i1.54099

National Council for Indigenous Policy (2016a). Resolução No. 001. http://www.funai.gov.br/index.php/cnpil/documentos

National Council for Indigenous Policy (2016b). Resolução No. 002. http://www.funai.gov.br/index.php/cnpi1/documentos

National Council for Indigenous Policy (2016c). Resolução No. 003. http://www.funai.gov.br/index.php/cnpil/documentos

National Council for Indigenous Policy (2016d). Resolução No. 004. http://www.funai.gov.br/index.php/cnpi1/documentos

National Council for Indigenous Policy (2016e). Resolução No. 005. http://www.funai.gov.br/index.php/cnpil/documentos

National Council for Indigenous Policy (2016f). Resolução No. 006. http://www.funai.gov.br/index.php/cnpi1/documentos

Oliveira, R. M. (2019). Terceira parte: Os protocolos de consulta. In C. F. M. Souza Filho, L. A. L. Silva, R. Oliveira, C. Motoki, \& V. Glass (Eds.), Protocolos de consulta prévia e o direito à livre determinação (pp. 109-258). São Paulo: Fundação Rosa Luxemburgo.

Pinheiro Filho, G. M., \& Silva, L. A. L. (2019). Protocolo de consulta prévia frente aos empreendimentos hidrelétrico e minerário na Amazônia: Caso Belo Monte e Belo Sun. Encontro Nacional de Antropologia do Direito, Vol. 6, 1-16.

Piovesan, F. (2017). Ius constitutionale commune latino-americano em Direitos Humanos e o Sistema Interamericano: Perspectivas e desafios. Revista Direito e Práxis, 8, 1356-1388. https://doi.org/10.12957/dep.2017.28029

Pontes Jr., F. (2019). Apresentação. In C. F. M. Souza Filho, L. A. L. Silva, R. Oliveira, C. Motoki, \& V. Glass (Eds.), Protocolos de consulta prévia e o direito à livre determinação (pp. 1-18). São Paulo: Fundação Rosa Luxemburgo.

Rossi, A. S. (2019). Direitos Fundamentais e Direitos Humanos: O estreitamento das fronteiras conceituais e a necessidade de um diálogo entre a órbita jurídica interna e internacional. Opinión Jurídica, 18, 209-230. https://doi.org/10.22395/ojum.v18n37a8

Santano, A. C. (2019). Direitos sociais e desenvolvimento: Uma abordagem do ativismo judicial na Corte Interamericana de Direitos Humanos. Revista de Direito Administrativo \& Constitucional, 19, 273-300. https://doi.org/10.21056/aec.v19i77.1177

Silva, L. A. L. (2019a). Sujeitos da convenção n. 169 da Organização Internacional do Trabalho (OIT) e o direito à Consulta e ao Consentimento Prévio, Livre e Informado 
(CCPLI). In C. F. M. Souza Filho, L. A. L. Silva, R. Oliveira, C. Motoki, \& V. Glass (Eds.), Protocolos de consulta prévia e o direito à livre determinação (pp. 109-258). São Paulo: Fundação Rosa Luxemburgo.

Silva, L. A. L. (2019b). Jusdiversidade e autodeterminação: A força vinculante dos protocolos autônomos de consulta prévia. Encontro Nacional de Antropologia do Direito, 6, 1-15.

Souza Filho, C. F. M. (2012). O renascer dos povos indígenas para o direito. Curitiba: Juruá.

Souza Filho, C. F. M. (2019). A força vinculante do protocolo de consulta. In C. F. M. Souza Filho, L. A. L. Silva, R. Oliveira, C. Motoki, \& V. Glass (Eds.), Protocolos de consulta prévia e o direito à livre determinação (pp. 19-46). São Paulo: Fundação Rosa Luxemburgo.

Taylor, C. (2000). Argumentos filosóficos. São Paulo: Loyola.

Toerell, J., Torcal, M., \& Montero, J. R. (2007). Political Participation: Mapping the Terrain. In J. W. Van Deth, J. R. Montero, \& A. Westholm (Eds.), Citizenship and Involvement in European Democracies: A Comparative Analysis (pp. 334-357). London: Routledge.

United Nations News Center (2013). UN Expert Urges States to Treat Participation as "Fundamental Human Right". https://news.un.org/en/story/2013/05/440772\#.\%20VxvJDPkrLIV

Walsh, C. (2008). Interculturalidad, pluralidade y decolinialidad: Las insurgências político-epistêmicas de refundar el estado. Tabula Rasa, 9, 131-152.

https://doi.org/10.25058/20112742.343 